http://kitaibelia.unideb.hu/

ISSN 2064-4507 (Online) • ISSN 1219-9672 (Print)

(C) Department of Botany, University of Debrecen, Hungary

23 (2): 207-217.; 2018

DOI: $10.17542 /$ kit.23.207

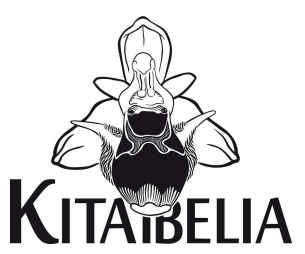

\title{
Florisztikai felmérések hibaforrásai I. „Jószándékú” flórahamisítások: „kakukk” a Medvesen
}

\author{
CSIKY János ${ }^{1 *} \&$ LANTOS István ${ }^{2}$
}

(1) PTE, TTk, Biológiai Intézet, Ökológiai Tsz., H-7624 Pécs, Ifjúság u. 6.; *moon@gamma.ttk.pte.hu (2) Bükki Nemzeti park Igazgatóság, H-3304 Eger, Sánc utca 6.

\section{The biases of floristic surveys I. Naive planters: “cuckoo" of the Medves (N Hungary)}

\begin{abstract}
The aim of the planned thematic studies is to point out the main biases and/or errors of floristic surveys in Hungary. In this first article of the series we focus on those examples when native species were planted out of their original habitats and/or range by a non-professional naturalist. The sources of information are those letters that were posted by Ferenc Varga to the first author of this article in 2005. The circumstances of the transplantation of 10 phytogeographycally significant species of the investigated area and/or the Pannonicum (Adonis vernalis, Arum orientale, Asarum europaeum, Genista germanica, Phragmites australis, Pulsatilla grandis, P. nigricans, Salvia aethiopis, Viola alba, Xeranthemum annuum) are detailed in the text and summarised in a table. The correspondence between the first author and Ferenc Varga provides insight how the ambition of a non-professional naturalist can influence the flora of an area. Most of the species were removed from South and transplanted to North, almost $10 \mathrm{~km}$ away from their original stands. With the exception of Adonis vernalis and Genista germanica at least one transplantation of the species was successful. In the case of Salvia aethiopis, the naturalized populations came $1.25 \mathrm{~km}$ close to Slovakia, where this species is a very rare and endangered (EN) taxon.
\end{abstract}

Keywords: basalt, cemetery, Moesz-line, native species, sandstone, transplantation

Összefoglalás - A tervezett cikksorozat a florisztikai térképezések, illetve az így keletkezett adatbázisok hibaforrásaira szeretné felhívni a figyelmet. E dolgozatban elsőként a „jószándékú" flórahamisítás esetét mutatjuk be egy kistáj, a Medves vidék példáján. Az adatok forrását azok a 2005-ben postázott levelek képezik, amelyeket Varga Ferenc az elsőszerző kérésére fogalmazott meg. A dolgozatban 10, a tájegység és/vagy a Pannonicum szempontjából növényföldrajzilag is jelentős faj (Adonis vernalis, Arum orientale, Asarum europaeum, Genista germanica, Phragmites australis, Pulsatilla grandis, P. nigricans, Salvia aethiopis, Viola alba, Xeranthemum annuum) átültetésének körülményeit listázzuk. A levelezésekből kiderül, hogy amatőr botanikusként milyen módon szólhatunk bele egy terület flórájának alakulásába. A fajok döntő részét Varga Ferenc déli irányból észak felé mozdította el, átlagosan mintegy 10 km-nyire az eredeti termőhelyüktől. Az Adonis vernalis és a Genista germanica kivételével legalább egy áttelepítés sikeresen, meghonosodással végződött. A Salvia aethiopis esetében az új állomány csupán 1,25 km-nyire található Szlovákiától, ahol a faj már kifejezetten ritka, veszélyeztetett (EN) taxon.

Kulcsszavak: bazalt, homokkő, Moesz-vonal, őshonos fajok, telepítés, temető 


\section{Bevezetés}

Soó Rezső synopsis-a óta (Soó 1964-1980) nem született olyan összefoglaló florisztikai munka, amely országos léptékben, új szemszögből nyújtott volna betekintést az edényes növényfajok elterjedési mintázatainak rejtelmeibe. Mindez múlt időben értendő, ui. a nemrégiben megjelent Atlas Florae Hungariae pont ezt a hiányt igyekszik pótolni (BARTHA et al. 2015). E nagyívű alkotást száznál is több botanikus összehangolt terepi és adminisztratív munkájának köszönhetjük. Nagy előrelépésről van szó ahhoz képest, hogy a 20. század elején MoEsz Gusztáv (1911) még csak néhány faj elterjedési adatai alapján pontosította a Carpaticum és Pannonicum közötti flórahatárt. Fontos megemlíteni, a folytonos lefutású, több száz km hosszú „Moesz-vonalhoz” képest az akkoriban rendelkezésre álló, areahatárokat reprezentáló adatok mennyisége fajonként nem, vagy alig haladta meg a tízet. Ennek következtében a térbeli felbontás meglehetősen durvaszemcsés, több száz, akár ezer km²-esre tehető. (Sokszor nem követhető, hogy a dolgozatban milyen információ birtokában vesz ilyen finom kanyarokat egy-egy faj elterjedésének határvonala; a bizonytalanságokról azonban a szerző is említést tesz.) Ez a felbontás a flórajárások léptéke, s annak ellenére, hogy az elmúlt száz évben az adatok mennyisége (nem egyenletes eloszlásban ugyan, de) nagyságrendileg növekedett, az országos léptékű florisztikai munkák, növényföldrajzi dolgozatok (JÁvORKA 1925, SoÓ 1964-1980, FARKAS 1999, SIMON 2000, KIRÁLY 2009) a legutóbbi időkig is leginkább csak ezen a szinten számoltak el az edényes növények hazai elterjedésével. A több fajt is tárgyaló, ennél finomabb léptékben tett országos, vagy annál nagyobb területet érintő próbálkozások során (vö. SRAMKó 2004) a megfelelő források hiányában csak nagy bizonytalanságok mellett vonhattak le következtetéseket a kutatók.

A jó hír (ti. a megközelítőleg $35 \mathrm{~km}^{2}$-es felbontású ponttérképek megjelenése) ellenére azt is tudjuk, hogy a rendelkezésre álló adatok birtokában még nem, vagy csak körültekintéssel foghatunk hozzá a nóvumokkal kecsegtető elterjedési mintázatok numerikus elemzéséhez, leíró statisztikai értékeléséhez (vö. BARTHA \& TiBORCz 2017).

Ha nullhipotézisnek $\left(\mathrm{H}_{0}\right)$ a flóratérképek esetében „a faj hiányát” tekintjük, akkor az atlasz tanulmányozása során az alábbi, alapvető hibatípusokkal szembesülhetünk:

1. elsőfajú hiba: a faj szerepel az atlaszban, de a valóságban az adott kvadrátban nem fordul elő (nincs hiteles forrás, pl. bizonyító fotó, példány).

2. másodfajú hiba: a taxon jelen volt a kvadrátban, de egyedeit a felmérő nem mutatta ki.

A fenti hibatípusokkal és következményeikkel a tervezett cikksorozat következő dolgozatában részletesebben is foglalkozunk, ebben a munkában azonban egy speciális esetre szeretnénk felhívni a figyelmet (s egy régi tartozásunkat is igyekszünk törleszteni ezzel). Mivel a flóraatlasz megkülönbözteti a meghonosodott állományokat a honosoktól, ezért az elsőfajú hiba (1.) speciális aleseteként is kezelhetjük azt a jelenséget, amikor egy regionálisan őshonosnak tekintett faj (pl. Ribes uva-crispa) jól dokumentált adatok mellett valóban jelen van a területen, de lokálisan csak a szándékos betelepítést követően honosodott meg. Ez akkor válik valódi mintavételi hibává (ún. bias-szá), ha a betelepítés ténye (pl. szimbólumok formájában) a térképeken nem jelenik meg. Egy ilyen beavatkozás (telepítés), ha nem vállalati, gazdasági érdekből történik (pl. erdő- és rétgazdálkodás esetében a Fraxinus ornus az Északi-középhegységben és az Arrhenaterium elatior az Alföldön), az ún. „jószándékú” flórahamisítás esete, amellyel történeti dokumentumok hiányában chorológiai elemzések során nem sokat lehet kezdeni, ám a flóraadatbázisok kiértékelése szempontjából jelentősége nem elhanyagolható.

Jelen dolgozatban ezzel a sokszor „kiszűrhetetlen” zajjal („florisztikai kakukktojásokkal”) szeretnénk behatóbban foglalkozni, az Északi-középhegység egyik határ menti kistáján, a 
Medves vidék példáján, ott, ahol a korábban említett Moesz-vonalhoz simuló area-határvonalak a leginkább összesűrűsödnek (MoEsz l.c.). Dolgozatunkkal buzdítani szeretnénk azokat a helyi ismerettel rendelkező terepbiológusokat, akik hasonló információk birtokában vannak, így publikációikkal hatékonyan segíthetnék a fajok elterjedését kutató botanikusok munkáját. Annak ellenére, hogy a fajok szándékos betelepítése, a flóra antropogén átalakítása már évezredek óta hatékonyan zajlik (lásd kétfázis elmélet, BoRos 1952), az elmúlt századokban történt „hamisítások” megismerése alapvető fontossággal bír (vö. HANGAY 1889, JuHÁsz 1967, 1968). Ezekben az esetekben ui. a Kárpát-medencében őshonos fajok áttelepítése az újjövevények megjelenésével egy időben zajlik, s általában csak látszólagos, ám olykor igen látványos expanzióval jár (pl. Telekia speciosa vö. FARKAS 1999, KIRÁLY 2004, SIMON et al. 2007, SZMORAD 2011, BARTHA et al. 2015), ami az özönfajokhoz hasonló, de annál összetettebb természetvédelmi problémákhoz, dilemmákhoz vezethet (pl. kiirtható-e egy őshonos, de behurcolt vagy betelepített védett növény).

\section{Anyag és módszer}

A Medves környékén alkotó Varga Ferenc (Inászó, 1930 - Salgótarján, 2006; 1988-tól az MME örökös tagja), elsősorban madarász volt, s leginkább a kakukkok terén elért eredményeiről volt szakmai körökben híres (VARGA 1994), de egyéb madárfajok esetében is szakemberként tartották számon (HARASZTHY 1998). Feri bácsi kiváló lokálpatriótaként nem csak madarak érdekelték, számos ritka növényfaj előfordulásának felfedezése is a nevéhez fűződik (CSIKY 2004). A növényekre a rendszerváltás környékén kezdett jobban odafigyelni, miután a Kertészeti és Élelmiszeripari Egyetem oktatói és hallgatói kutatni kezdték a bazaltvidék sziklafelszíneit (vö. FELHőSNÉ et al. 1996), s őt kérték fel, hogy terepbejárásaikon kalauzolja őket a környéken.

Mint a vidéken élő és kutató ifjonc, e cikk elsőszerzője az 1990-es évek elején ismerkedett meg Varga Ferenccel, akivel csak pár alkalommal volt közös terepbejáráson, ám a halála előtti években több levelet is váltottak a helyi flóra sokszínűségének eredetével kapcsolatban. Kérésére Feri bácsi részletesen listázta azokat a fajokat, amelyeket szándékosan vetett, vagy telepített a Medves környékén. Mindez sajnos a flóramű (CSIKY 2004) megjelenése után történt, így ezek a kiegészítő információk nyomtatásban még nem jelentek meg.

A növénytelepítési kísérleteiről Feri bácsi így ír: „A Medves tájain barangolva feltűnt, hogy sok olyan növény hiányzik innét, ami kissé délebbre már gyakori. Ezért elhatároztam, hogy megpróbálok néhány fajt ültetni, magjait elszórni. Az alábbiakban felsorolok olyan fajokat is, melyek a Medvest övező völgyekben gyakori, de a fennsíkról hiányzott."

Az Enumerációban külön listázzuk azokat a fajokat, amelyeket Feri bácsi szándékosan, de sikertelenül telepített. Ezeknek a jelentősége abban áll, hogy rámutatnak a faj lokális termőhelyi, megtelepedési korlátaira, ill. jól példázzák azt, hogy a lokálisan ritka fajok közül melyek azok, amelyek elterjedési határuk közelében emberi segítséggel sem mindig honosíthatók meg.

A fajok lelőhelyeit kiegészítettük a megfelelő KEF kódokkal, a lelőhelyek koordinátáival (WGS84), valamint a pontos idézetek után külön megjegyzésben tárgyaljuk a növény lokális (CSIKY 2004) és regionális (BARTHA et al. 2015) elterjedésének fontosabb aspektusait, s ahol az adatok rendelkezésre álltak, a telepített állományok aktuális állapotát is. Az adatokat táblázatba rendezve a lelőhelyek centrális koordinátái alapján kiszámoltuk a forrás és a telepítés helye közötti távolságot és megadtuk az elmozdítás irányát (1. táblázat).

A levelezés során megemlített fajok nomenklatúrája KIRÁLY (2009) munkájához igazodik. 
Kitaibelia 23 (2): 207-217.

1. táblázat Varga Ferenc által dokumentált Medves vidéki telepítési kísérletek és eredményességük Table 1. The results of vascular plant transplantations in the Medves region (performed and documented by Ferenc Varga)

\begin{tabular}{|c|c|c|c|c|c|c|}
\hline 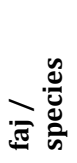 & ఏే & $\underset{\substack{0 \\
0 \\
0}}{3}$ & 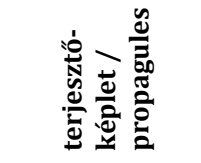 & 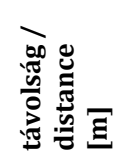 & 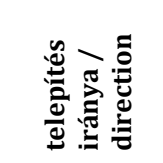 & 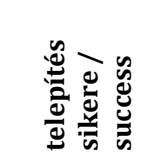 \\
\hline 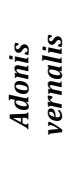 & $\begin{array}{l}\text { Mátraterenye: } \\
\text { Körös-Magos } \\
7985.4 \\
\text { N } 48.00870^{\circ} \\
\text { E } 19.94272^{\circ}\end{array}$ & $\begin{array}{l}\text { Salgótarján: } \\
\text { Tehenesi kőfejtő } \\
7885.3 \\
\text { N } 48.14538^{\circ} \\
\text { E } 19.89227^{\circ}\end{array}$ & $\begin{array}{l}\text { teljes növény / } \\
\text { whole plant } \\
\text { mag / seed }\end{array}$ & 15700 & ÉÉNy/NNW & $\begin{array}{l}\text { sikertelen / } \\
\text { failed }\end{array}$ \\
\hline 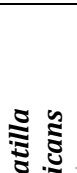 & $?$ & $\begin{array}{l}\text { Salgótarján: } \\
\text { Kis-bánya } \\
7885.1 \\
\text { N } 48.15386^{\circ} \\
\text { E } 19.85991^{\circ}\end{array}$ & mag / seed & $?$ & $?$ & $\begin{array}{l}\text { sikertelen / } \\
\text { failed }\end{array}$ \\
\hline 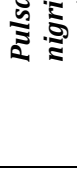 & $\begin{array}{l}\text { Bárna: Szerkő } \\
7885.4 \\
\text { N } 48.11583^{\circ} \\
\text { E } 19.93587^{\circ}\end{array}$ & $\begin{array}{l}\text { Salgótarján: } \\
\text { Kis-bánya } \\
7885.1 \\
\text { N 48.15386 } \\
\text { E 19.85991 } \\
\end{array}$ & $\begin{array}{c}\text { teljes növény / } \\
\text { whole plant } \\
\text { mag / seed }\end{array}$ & 7000 & ÉNy/NW & $\begin{array}{l}\text { sikeres / } \\
\text { successful }\end{array}$ \\
\hline 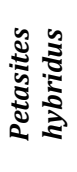 & $\begin{array}{l}\text { Salgótarján: } \\
\text { Inászó (?) } \\
7985.1 \\
\text { N } 48.097058^{\circ} \\
\text { E } 19.858487^{\circ}\end{array}$ & $\begin{array}{l}\text { Salgótarján: } \\
\text { Medves-Gortva v. } \\
7885.3 \\
\text { N } 48.13967^{\circ} \\
\text { E } 19.90903^{\circ}\end{array}$ & $\begin{array}{l}\text { teljes növény / } \\
\text { whole plant }\end{array}$ & $5100(?)$ & ÉK(?) & $\begin{array}{l}\text { sikertelen / } \\
\text { failed }\end{array}$ \\
\hline & $\begin{array}{l}\text { Mátraszelei régi } \\
\text { vadászházhoz } \\
\text { vezető út }\end{array}$ & $\begin{array}{l}\text { Salgótarján: } \\
\text { Gortva-völgy } \\
7885.3 \\
\text { N } 48.142434^{\circ} \\
\text { E } 19.889292^{\circ}\end{array}$ & $\begin{array}{l}\text { teljes növény / } \\
\text { whole plant }\end{array}$ & 7300 & ÉÉNy/NNW & $\begin{array}{l}\text { sikertelen / } \\
\text { failed(?) }\end{array}$ \\
\hline 交 & $\begin{array}{l}7985.1 \\
\text { N } 48.07877^{\circ} \\
\text { E } 19.91408^{\circ}\end{array}$ & $\begin{array}{l}\text { Salgótarján: } \\
\text { Bugyizló-árok } \\
7885.3 \\
\text { N } 48.126294^{\circ} \\
\text { E } 19.870734^{\circ}\end{array}$ & mag / seed & 6100 & ÉNy/NW & $\begin{array}{l}\text { sikertelen / } \\
\text { failed }\end{array}$ \\
\hline & $\begin{array}{l}\text { Bárna: } \\
\text { Gyalogút árok } \\
7985.2 \\
\text { N } 48.07981^{\circ} \\
\text { E } 19.91809^{\circ}\end{array}$ & $\begin{array}{l}\text { Salgótarján: } \\
\text { Rónai Buda-völgy } \\
7885.3 \\
\text { N } 48.11945^{\circ} \\
\text { E } 19.87959^{\circ}\end{array}$ & $\begin{array}{l}\text { teljes növény / } \\
\text { whole plant }\end{array}$ & 5300 & Ény/NW & $\begin{array}{l}\text { sikeres / } \\
\text { successful }\end{array}$ \\
\hline \multirow{3}{*}{ 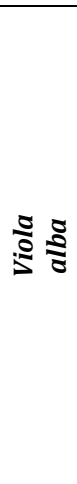 } & \multirow{2}{*}{$\begin{array}{l}\text { Kazár: Jánosakna } \\
\text { melletti Csibaj } \\
7985.4 \\
\text { N } 48.03484^{\circ} \\
\text { E } 19.91731^{\circ}\end{array}$} & $\begin{array}{l}\text { Zagyvaróna } \\
\text { feletti akácos } \\
7885.3 \\
\text { N } 48.13336^{\circ} \\
\text { E } 19.86058^{\circ}\end{array}$ & $\begin{array}{l}\text { teljes növény / } \\
\text { whole plant }\end{array}$ & 11700 & ÉÉNy/NNW & $\begin{array}{l}\text { sikertelen / } \\
\text { failed }\end{array}$ \\
\hline & & $\begin{array}{l}\text { Hársas-árok } \\
7885.3 \\
\text { N } 48.11906^{\circ} \\
\text { E } 19.86940^{\circ}\end{array}$ & $\begin{array}{l}\text { teljes növény / } \\
\text { whole plant }\end{array}$ & 10000 & ÉÉNy/NNW & $\begin{array}{l}\text { sikertelen / } \\
\text { failed }\end{array}$ \\
\hline & $\begin{array}{l}\text { Kazár: } \\
\text { Jánosakna, Csibaj } \\
7985.4 \\
\text { N } 48.03484^{\circ} \\
\text { E } 19.91731^{\circ}\end{array}$ & $\begin{array}{l}\text { Salgótarján: } \\
\text { Buda-völgy } \\
7885.3 \\
\text { N } 48.11945^{\circ} \\
\text { E } 19.87959^{\circ}\end{array}$ & $\begin{array}{l}\text { teljes növény / } \\
\text { whole plant }\end{array}$ & 9800 & ÉÉNy/NNW & $\begin{array}{l}\text { sikeres / } \\
\text { successful }\end{array}$ \\
\hline
\end{tabular}


CSIKY \& LANTOS (2018): Florisztikai felmérések hibaforrásai I.

\begin{tabular}{|c|c|c|c|c|c|c|}
\hline 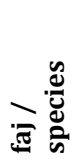 & 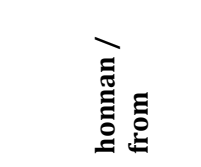 & 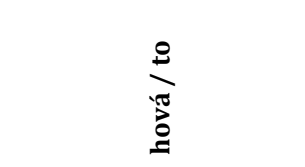 & 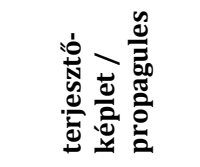 & 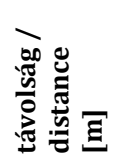 & 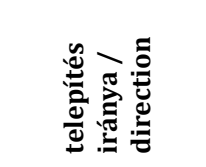 & 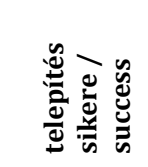 \\
\hline 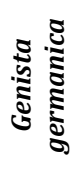 & $\begin{array}{l}\text { Mátranovák: } \\
\text { Hegyeske } \\
7985.2 \\
\text { N } 48.06969^{\circ} \\
\text { E } 19.93142^{\circ}\end{array}$ & $\begin{array}{l}\text { Salgótarján: } \\
\text { Tehenesi-kőfejtő } \\
7885.3 \\
\text { N } 48.14538^{\circ} \\
\text { E } 19.89227^{\circ}\end{array}$ & $\begin{array}{l}\text { teljes növény / } \\
\text { whole plant }\end{array}$ & 8900 & ÉÉNy/NNW & $\begin{array}{c}\text { sikertelen / } \\
\text { failed }\end{array}$ \\
\hline \multirow{3}{*}{ 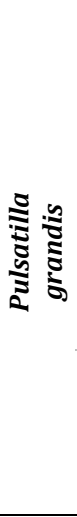 } & \multirow{2}{*}{$\begin{array}{l}\text { Mátranovák: } \\
\text { Hegyeske } \\
7985.2 \\
\text { N } 48.06969^{\circ} \\
\text { E } 19.93142^{\circ}\end{array}$} & $\begin{array}{l}\text { Salgótarján: } \\
\text { Zagyvaróna, sírhely } \\
7885.3 \\
\text { N } 48.12750^{\circ} \\
\text { E } 19.85822^{\circ}\end{array}$ & $\begin{array}{l}\text { teljes növény / } \\
\text { whole plant }\end{array}$ & 8400 & ÉNy/NW & $\begin{array}{l}\text { sikeres / } \\
\text { successful }\end{array}$ \\
\hline & & $\begin{array}{l}\text { Salgótarján: } \\
\text { Tehenesi-kőfejtő } \\
7885.3 \\
\text { N } 48.14538^{\circ} \\
\text { E } 19.89227^{\circ}\end{array}$ & $\begin{array}{l}\text { teljes növény / } \\
\text { whole plant }\end{array}$ & 8900 & ÉÉNy/NNW & $\begin{array}{l}\text { sikeres / } \\
\text { successful }\end{array}$ \\
\hline & $\begin{array}{l}\text { Mátranovák: } \\
\text { Hegyeske } \\
7985.2 \\
\text { N } 48.06969^{\circ} \\
\text { E } 19.93142^{\circ} \\
\end{array}$ & $\begin{array}{l}\text { Salgótarján: } \\
\text { Kis-bánya } \\
7885.1 \\
\text { N } 48.15386^{\circ} \\
\text { E } 19.85991^{\circ} \\
\end{array}$ & mag / seed & 10800 & ÉNy/NW & $\begin{array}{c}\text { sikertelen / } \\
\text { failed }\end{array}$ \\
\hline 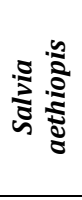 & $\begin{array}{l}\text { Mátraszele: } \\
\text { Darazsik és } \\
\text { a Pétervölgy(?) } \\
7985.2 \\
\text { N } 48.05322^{\circ} \\
\text { E } 19.92845^{\circ}\end{array}$ & $\begin{array}{l}\text { Salgótarján: } \\
\text { Tehenesi-kőfejtő } \\
7885.3 \\
\text { N } 48.14538^{\circ} \\
\text { E } 19.89227^{\circ}\end{array}$ & $\begin{array}{l}\text { teljes növény / } \\
\text { whole plant } \\
\text { mag / seed }\end{array}$ & 10600 & ÉÉNy/NNW & $\begin{array}{l}\text { sikeres / } \\
\text { successful }\end{array}$ \\
\hline 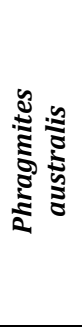 & $?$ & $\begin{array}{l}\text { Salgótarján: } \\
\text { Gortva-tó } \\
7885.3 \\
\text { N } 48.14174^{\circ} \\
\text { E } 19.88800^{\circ} \\
\text { Medves Hotel }^{\circ} \\
\text { feletti horpadás } \\
7885.3 \\
\text { N } 48.14383^{\circ} \\
\text { E } 19.87400^{\circ} \\
\end{array}$ & $\begin{array}{l}\text { teljes növény / } \\
\text { whole plant }\end{array}$ & $?$ & $?$ & $\begin{array}{l}\text { sikeres / } \\
\text { successful }\end{array}$ \\
\hline 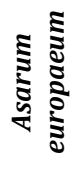 & $\begin{array}{l}\text { Mátraszele: } \\
\text { Gábor-völgy } \\
7985.1 \\
\text { N } 48.060316^{\circ} \\
\text { E } 19.886386^{\circ}\end{array}$ & $\begin{array}{l}\text { Salgótarján: } \\
\text { Buda-völgy, alsó kútház } \\
7885.3 \\
\text { N } 48.11906^{\circ} \\
\text { E } 19.87845^{\circ}\end{array}$ & $\begin{array}{l}\text { teljes növény / } \\
\text { whole plant }\end{array}$ & 6600 & É(ÉNy)/N(NW) & $\begin{array}{l}\text { sikeres / } \\
\text { successful }\end{array}$ \\
\hline 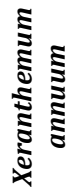 & $?$ & $\begin{array}{l}\text { Salgótarján: } \\
\text { Tehenesi-kőfejtő } \\
7885.3 \\
\text { N } 48.14538^{\circ} \\
\text { E } 19.89227^{\circ}\end{array}$ & mag / seed & $?$ & $?$ & $\begin{array}{l}\text { sikeres / } \\
\text { successful }\end{array}$ \\
\hline
\end{tabular}




\section{Enumeráció}

\section{Sikertelen telepítések}

Adonis vernalis L. - „2001-ben 5 tövet hoztam a Nádujfalu és Nemti közötti hegyoldalból (feltehetőleg a Mátraterenye: Körös-Magos nevű ma is létező lelőhelyről [beszúrás a szerzőktől: 7985.4]. Telepítés helye: Tehenesi kőfejtő (beszúrás a szerzőktől: Salgótarján [7885.3]). Sajnos egy sem állt be, kivétel nélkül elpusztultak. Magját is szórtam szét, de semmi jelét nem látom annak, hogy kelne ki belőle.” „A Tehenesi-kőfejtőbe ültetett Tavaszi hérics egyszerűen nem állt be."

Megj.: A regionálisan meszes és löszös napfényes felszínekhez kötődő tavaszi hérics a Karancs és Medves vidékén kifejezetten ritka, szinte unikális fajjá válik, s a másutt szokásos termőhelyein (sziklagyepek, félszáraz gyepek, molyhos tölgyesek szegélyei) gyakorlatilag hiányzik (vö. CSIKY 2004). A telepítés kudarca elsősorban a terület klimatikus adottságaira, s a délies oldalak vályog frakcióban szegény, a hagyományos szőlőfajták termesztésére is alkalmatlan talajaira vezethető vissza (vö. MoEsz 1911). A bazaltvidék szlovák oldalán gyakorlatilag hiányzik, bár északabbra is ismert két perifériális, elszigetelt állománya (CSIKY 2004).

Pulsatilla nigricans Störck - „Két éve a Kis bányába (Salgótarján [7885.1]) is szórtam szét Fekete kökörcsin magot, ezidáig nem tapasztaltam, hogy kibújt volna akár egy is".

Megj.: bár név szerint itt nem tér ki a P. grandis sikertelen telepítésére, de másutt (lásd sikeres telepítések) szóba hozza, hogy a leánykökörcsin magvait is szétszórta a bánya területén.

Petasites hybridus (L.) G. Gaertn., B. Mey. et Scherb. - „A Medvesre történő növény (virág) telepítéseim sem járnak sikerrel. Volt rá eset, hogy a Gortva-völgybe (Salgótarján [7885.3]) telepített acsalaput kitúrták és megették a vaddisznók."

Megj.: A hegy- és dombvidéki patakparti magaskórósok jellegzetes, de hazánkban aggregált eloszlást mutató faja az Északi-középhegység Ny-i felében meglehetősen ritkának számít (BARTHA et al. 2015). A bazaltvidéken már olyan ritka, hogy itt az országos viszonylatban jóval ritkább és védett rokona, a Petasites albus is gyakoribb nála (CSIKY 2004), s a telepítés helyén, a Gortva-völgyben is csak ez a faj fordul elő. Valószínűsíthető, hogy a telepített tövek a levelezés során többször is emlegetett inaszói (Salgótarján [7985.1]) acsalapus területről származnak, ahol „... árnyékos helyen...” a vörös acsalapu ma is megtalálható (CSIKY ined.).

Arum cf. orientale M. Bieb. - „Másodszor a Mátraszelei régi vadászházhoz vezető út (Mátraszele [7985.1]) melletti cseres részen szedtem (itt rendkívül sok tenyészik). A telepítés 1999-ben történt a Bugyizló árokba, Gortva-völgyi bükkös forrás környéke, a Tehenesi kőfejtő bejárat előtt (Salgótarján [7885.3]), balra lévő füzfás rész és a kőfejtő fölötti lapos rész. Mindkét esetben magját is szedtem és szórtam el, de ezekből nem kelt ki.” „Ugyancsak a Kontyvirág gumói sem kedvelik ezt a köves talajt".

Megj.: Feri bácsi a levelében Arum maculatum-ot ír, ám e faj a térségben nem fordul elő. Megjegyzésre érdemes, hogy 2011.03.29-én egy leveles töve került elő a jelzett terület (Gortvavölgy) közelében, a salgótarjáni Rókalyuk gyepnél [7885.3] (Lantos ined.). Nem zárható ki, hogy ez esetben is Feri bácsi (sikeres) telepítési kísérleteinek egyikéről van szó. Az $A$. orientale a 7985.1-re új, az atlaszban nem szereplő adat! A bazaltvidék szlovák oldalán teljesen hiányzik (vö. CSIKY 2004).

Viola alba Besser - „... a 70-es évek közepén hoztam a Csibajnak nevezett Jánosakna melletti részből. Telepítés helye a ... Zagyvaróna fölötti akácos, valamint Hársas árok (Salgótarján [7885.3]). A községünk fölötti akácosból kipusztult, míg a Hársasban valaki tövestől kiszedte." 
Megj.: A Dunántúlon, főleg a domb- és hegyvidéki régióban elterjedt faj az Északiközéphegységben súlypontosan a Ny-i félben jellemző, keleten már inkább ritka. A bazaltvidéken a cseres-tölgyes zónához és a meleg, déli verőkhöz kötődő szórványos, a szlovák oldalon már ritka növény (CSIKY 2004). A V. alba a 7985.4-re új, az atlaszban nem szereplő adat!

Genista germanica L. - „2002-ben 4 tövet hoztam a Hegyeskéből (Mátranovák [7985.2]), a Tehenesi kőfejtőbe (Salgótarján [7885.3]) ültettem őket, annak ellenére, hogy naponta öntöztem, kivétel nélkül elszáradtak. Említést érdemel, hogy az eredeti helyén is kipusztult, mivel a tenyészőhelyét benőtte az erdő!"

Megj.: Domb- és hegyvidékeink mészkerülő erdeinek, erdőszegélyeinek, sovány legelőinek jellemző, ám viszonylag ritka faja (BARTHA et al. 2015), amely a területen a legeltetés viszszaszorulásával eltünőben van, de korábban is kifejezetten ritka volt (vö. CsıкY 2004). A G. germanica a 7985.2-re új, az atlaszban nem szereplő adat!

\section{Sikeres telepítések}

Pulsatilla nigricans Störck - „Az előzőtől eltérően egy évvel később hoztam a Szerkő (Bárna [7885.4]) gerinci tenyészőhelyéről. A hozott 4 tőből csak kettő állt be, virágot még nem hozott. Mindkét Pulsatilla fajnak sok magját szedtem és szórtam szét a Kis-bányában is (Salgótarján [7885.1])."

Megj.: a fekete és a leánykökörcsin a Bárna-Cered-Mátranovák körüli homoki legelőkön, száraz gyepekben elterjedt, néhol tömeges faj. Mindkét kökörcsinfaj bazalton is tenyészik, a $P$. nigricans azonban elterjedtebb, $\mathrm{s}$ andeziten csak ez jelenik meg. Megjegyzendő, hogy a $P$. nigricans-nak kb. 100 töves állományát mutatták ki a Kis-Bányában 2015-ben (LANTos ined.), míg a P. grandis azóta sem került elő innen. A P. nigricans a 7885.1-re új, az atlaszban nem szereplő adat! Ugyanebben a kvadrátban, a szlovák oldalon több állománya is ismert.

Pulsatilla grandis Wender. - „... amikor a Hegyeskéből (Mátranovák [7985.2]) hoztam néhány tő leánykökörcsint”. A levélből kiderül, hogy a telepítés 2001-ben történt, $\mathrm{s}$ „,...ezeket csaknem mind a vaddisznó túrásokból” szedte össze. A töveket „... a Tehenesi kőfejtő alsó, lapos részén” ültette el. „2004-ben 3 virágzó töve volt (6,-4 és 5 virággal).” Szintén Hegyeskéről, egy másik, különlegesnek tűnő, „....vaddisznótúrás szélén lévő tövet elhoztam és elültettem a temetőbe a feleségem sírja fölötti partoldalba be is állt...”.

Megj.: A határ magyar oldalán a leánykökörcsin bazalton csak a Nagy-Salgón és Boszorkánykőn jelenik meg, a szlovák oldalon több sziklakibúváson is. Andezitről teljesen hiányzik (a Karancson homokkövön él). Homokkövön és málladékán elterjedtebb. Ez az eset azt is jól példázza, hogy a ritka, védett fajokat rejtő temetők flórája nem kizárólagosan spontán megtelepedések eredménye (vö. MoLNÁR V. \& LÖKI 2018). Szépségük miatt feltehetően korábban is hozták, vitték, telepítették e növényeket az emberek. Megjegyzésre érdemes, hogy a jelzett síron azóta is 1 tő $P$. grandis és 1 tő $P$. grandis $\times$ P. nigricans (det. SulYoK J.) virul. A hibrid tő jelentőségével (lásd fent) Feri bácsi is tisztában volt: „... találtam egy később virágzó 8 virágos tövet...” (ti. Hegyeskén). „Ezek a virágok sötétebbek voltak az eredeti virágoktól, de a fekete kökörcsinétől viszont világosabbak! ... A mellette lévő leány és fekete kökörcsin már hajt...” (ti. a síron). „Lehetségesnek tartom, hogy hibriddel van dolgom? ... a nyíló virágok az ég felé néznek és csak később bókolnak."

Salvia aethiopis L. - „Ebből is két ízben hoztam és telepítettem. Először a 90-es évek első felében hoztam a Darazsik és a Pétervölgy közötti részről (Homokterenye [7985.4]). Ekkor kb. 15 tövet szedtem szántóterületen. Telepítés helye: a Tehenesi kőfejtő (Salgótarján [7885.3]) felső és alsó laposabb rész, valamint a kőfejtő fölötti füves rész (innét kipusztult). Ezt követően 2000 őszén hoztam töveket, de sok magot is elszórtam, ezekből sok kikelt és a 
következő évben már virágot is hoztak. Úgy látszik, hogy ezt a helyet kedveli. Az elmúlt évben a köves rész fölötti részen több mint 20 tövet számoltam meg. Itt most már önmaguktól (magról) szaporodnak. Érdemesnek tartom megemlíteni, hogy a virágjaira csak apróbb legyek és a fémdarazsak járnak, illetve a beporzást ezek végzik!” „,... a Tehenesi kőfejtőben szépen szaporodik."

Megj.: A MoEsz (1911) által kiválasztott fajok egyike, az Alföld és a Dunántúli-khg. löszterületein, meszes talajú, félszáraz legelőin szórványos, az Északi-középhegységben már ritka, csak a Ny-i felében szórványos. A bazaltvidéken csak egy régi irodalmi adat utal a jelenlétére (CSIKY 2004). A homokterenyei részeken ma is bőven tenyészik (vö. SRAmkó et al. 2008). Megjegyzésre érdemes, hogy a fent jelzett területről a fajnak nincs ismert előfordulási adata, de ugyanazon vonulat délebbi, mintegy 2500 m-re eső szakaszán, a Mogyorós-tető dűlőben ma is megtalálható (LANTOS ined.). A S. aethiopis a 7885.3-ra új, az atlaszban nem szereplő adat! Szlovákiában csak az ország Ny-i felében (Honttól Ny-ra) fordul elő, ritka, veszélyeztetett (EN) faj (ČEŘOvSKÝ et al. 1999). A számára megfelelő klímán, az antropogén termőhelyeket pionírként a környékbeli forráspopulációkból könnyen kolonizálja: pl. az M6-os autópálya 98. és 101. kilométertáblái között [Bölcske-Paks: Gyűrűs-árok környéke, 9279.3, 9379.1], a 8 éve átadott, rendszeresen kaszált rézsűkben ma már tömeges (CsiKY ined.).

Arum cf. orientale M. Bieb. - „Két ízben hoztam és telepítettem. Első ízben a 80-as évek második felében hoztam a Gyalogút árok felső végétől (Bárna [7985.2]). Telepítés helye: Budavölgy felső kútházzal szembeni árok vége, a luc és a vörösfenyők környéke, az alsó kútház utáni kanyar, valamint a völgy alsó végén balra húzódó akácos árok (Salgótarján [7885.3]).”, „... telepei a Medves déli nyúlványán találhatók (Salgótarján [7885.3])... Én úgy vélem, hogy csupán más helyre telepítettem a szóbanforgó növényeket."

Megj.: lásd sikertelen telepítések. A Salgótarjánhoz tartozó Rónai Buda-völgyben 2012.04.08án a kontyvirág 15-15 egyedét találták a fent említett első két lelőhelyen, míg az akácosból nem kerültek elő példányai (LANTOS ined.). Legközelebbi állományai Bárnán és Mátraszelén ismertek, mindenütt viszonylag kis (100 tő alatti) egyedszámmal. Az A. orientale a 7885.3-ra és a 7985.2-re új, az atlaszban nem szereplő adat!

Phragmites australis (Cav.) Steud. - „Egyik képen a Gortva-tó látható az általam telepített nádassal...” „Először a 70-es években hoztam töveket a Hotel Medves fölötti horpadásba (Salgótarján [7885.3]). Ezidőtájt csaknem egész évben víz állt itt. Később a Ceredi Tsz. lecsapolta... az összegyúlt víz leszivárgott innét, így a nád is kipusztult. A Gortva-tóba (Salgótarján [7885.3]) a 80-as évek végén telepítettem, hogy így megtelepednek itt a nádi poszáták és a nádi rigó."

Megj.: amint látható nem csak ritka, látványos, de egyébként is jól terjedő, tömeges „haszonnövények" telepítésébe is beleszólhat az ember. Noha a florisztikai tanulmányokban erre vonatkozóan nincsenek részletes adatok, de a nád, megfelelő élőhelyek hiányában korábban nem fordult elő a Medves-fennsíkon, illetve ma is csak a mesterséges vízfelszínek mentén fordul elő.

Viola alba Besser - „...a 70-es évek közepén hoztam a Csibajnak nevezett Jánosakna melletti részből (Homokterenye [7985.4]). Telepítés helye a Budavölgy alsó, cseres része (Salgótarján [7885.3])..."

Megj.: ez a telepítési kísérlet Feri bácsi jó élőhelyismeretéről tanúskodik. A fehér ibolya hasonló élőhelyeken a Karancs és Medves vidékén másutt is előfordul. A V. alba a 7985.4-re új, az atlaszban nem szereplő adat!

Asarum europaeum L. - „A 80-as évek elején hoztam a Mátraszele melletti Gáborvölgyből (akácos) (Mátraszele [7985.1]). (Azidőtájt még nem tudtam, hogy a Medvesen is tenyészik). Telepítés helye: Budavölgy alsó kútház, valamint a Hársas forrás körüli rész (Salgótarján 
[7885.3]). Ez utóbbi elég szépen terjeszkedik annak ellenére, hogy sokat kitaposnak az ott legeltetett kecskék."

Megj.: A Nógrád-Gömöri-bazaltvidék térségében (ahogy a Cserhát és Mátra területén is) ritka, csak a peremvidék völgyeiben (gyertyános-tölgyesek, ligeterdők) és a Medves plató környékén (ligeterdőkben, gyertyános-tölgyesekben, bükkösökben) fordul elő. A bazaltvidék szlovák oldalán elterjedtebb, gyakoribb. Az A. europaeum a 7985.1-re új, az atlaszban nem szereplő adat!

Xeranthemum annuum L. - „Az 1990-es évek óta több ízben is hoztam magját és szórtam el a Tehenesi kőfejtőben (Salgótarján [7885.3]). Azóta terjeszkedik, egyre több van belőle. Először csak a köves rész fölött voltak kisebb telepei, de már az alsó laposabb részen is megjelent."

Megj.: Ez a mészkedvelő pionír jellegú növény, a MoEsz (l.c.) által kiválasztott fajok egyike, az ország középső felében, a Dunántúli-középhegységben, az alföld peremi és Duna-Tisza közi löszfelszíneken elterjedt. Érdekes, hogy az Északi-középhegység Ny-i és K-i felében szinte hiányzik, míg a középső részein, homokkövön és löszön szórványos. Soó (1970) ugyan anemochor növénynek jelzi, azonban rövid, felfelé álló bóbitájának köszönhetően inkább epizoochor faj lehet. Ennek figyelembevételével könnyű elképzelni, hogy vándor pásztorkodás útján (vö. CsıKY 2004) is igen könnyen terjedhetett a D-T köze irányából az Északi-khg. középső részei felé (vö. BARTHA et al. 2015). É-i irányban hirtelen tűnik el, de Fülek-Ajnácskő környékén még szórványos (vö. CSIKY 2004). Csehországban már kipusztult faj (ČEŘovsKÝ et al. 1999). A flórahamisítás problémájának megemlítése után Feri bácsi a következőket írta: „... a vasvirág az 50-60-as években a Rónára vezető út mentén mindenütt virágzott.” Sajnos a leírásból nem derül ki, hogy honnan származnak a később ide került propagulumok, de feltételezhető, hogy a fent említett déli peremterületek egyikéről, ui. a Xeranthemum fajokat is tartalmazó listához ezt a megjegyzést füzte: „Medves, illetve a Hegyeske Déli vonulatairól valók". Egy 2005. 02. 15-én keltezett levelében az ékes vasvirág mellett a hengeres vasvirág (X. cylindraceum) medvesi ismert lelőhelyéről is ír, ám a pontos dűlőnév tisztázására később már nem került sor. Más források ez utóbbi fajt a bazaltvidékről nem említik.

\section{Eredmények megvitatása}

Az idézett sorok igen fontos információkat hordoznak arról, hogy milyen célból (ritkaság, szépség), hova (temető, kőfejtő, bányaudvar, forrás, mesterséges tavacskák) és milyen propagulumokat (tövek, magok) telepített át egy - a tájban otthonosan mozgó - 20. századi autodidakta lokálpatrióta. Jól ismert, hogy hasonló események durvább vagy azonos térléptékben az ország más tájain, más fajokkal is megtörténtek (HANGAY 1889, JUHÁsz 1967, 1968, MoLNÁr V. 1998, SOMLYAY 2007, NAGY 2017), ill. feltételezhető, hogy ez a fajta emberi tevékenység évszázadok, talán évezredek óta folyamatos, ma már lenyomozhatatlan hatást gyakorolt a Kárpát-medence flórájára. Megállapítható továbbá, hogy más esetekhez hasonlóan (vö. JUHÁSz 1967, 1968) a magvetés a Medves térségében is kisebb sikerrel járt, mint a kifejlett tövek elő- és utókezeléses átültetése.

Az adatokból kitűnik, hogy az áttelepítések forrás populációi Homokterenye térségében találhatók, ill. az átlagosan 10 km távolságban elhelyezkedő és ÉÉNy-ÉNy-ra fekvő Medvesfennsík környékén ültették, vetették őket. CSIKY (2004) értelmezése szerint a forrás állományok a Nógrád-Gömöri-bazaltvidék, a Heves-Borsodi-dombság és a Mátra közti határvidéken találhatók (s a telepítések a külön flórajárásnak is tekinthető bazaltvidék központjának D-i felét célozták meg). A klimatikus ökoton helyzetet reprezentáló térségben, a Szőlővonal mentén (MoEsz 1911) ilyen nagyságrendű, látszólag elhanyagolható, 1-2 magyarországi flóratérképezési kvadrátnyi ugrások (az edafikus, mezoklimatikus barrierek miatt) ko- 
molyabb emberi rásegítés (gondozás) nélkül már nem feltétlenül eredményeznek meghonosodást vagy alkalmi megtelepedést. Különösen olyan fajok esetében, amelyek sajátos antropogén beavatkozás hatására (többnyire legeltetés) képesek fennmaradni, ill. terjeszkedni a tájban (pl. Adonis vernalis, Genista germanica, Pulsatilla spp., Salvia aethiopis). Mindenesetre (bár a célirányosság e tekintetbe feltehetően kizárható) a telepítés a korunkra jellemző felmelegedés irányának megfelelően történt, D felől É-ra. Pontos adatok hiányában, illetve néhány konkrét utalás alapján feltételezzük, hogy mindezek a telepítések a rendszerváltás után, de döntően az ezredforduló elött történtek. Egyes esetekben meglepő, hogy az egyébként ritka, visszahúzódóban lévő fajok milyen gyors egyedszám növekedéssel reagáltak: a P. nigricans kis-bányai állománya 13 év alatt kettőről kb. 100 tőre növekedett, míg a Salvia aethiopis a Tehenesi kőfejtőben pár év alatt önfenntartó állományt produkált.

Sajnos arról nincs részletes információnk, hogy milyen előzetes (ökológiai, élőhelyismereti) tapasztalat alapján vetett célfajokat Feri bácsi, de tevékenysége bizonyos esetekben, némi túlzással egy bányarekultivációs kísérletnek is felfogható (pl. Tehenesi kőfejtő, Kis-bánya). Annyi bizonyos, hogy mindkét területet kiválóan ismerte. A forrás lelőhelyekről így ír: „A Mátraszelei részeket azért ismerem, mert 14 évig laktunk ott. Édesapám erdész volt azon a részen. Mivel én is szerettem a Természetet nagyon sokat jártam Vele terepre...".

Felmerülhet a gondolat, hogy hátrányai ellenére (pl. helyi állományokkal való keveredés, areatorzítás), a génállomány megőrzése szempontjából hasznos is lehet egy hasonló, kisvagy középtájon belüli áttelepítés, ám ezzel senkit sem szeretnénk buzdítani a fajok ilyen célú ide-oda hurcolására, mivel ez a módszer a feltételezett haszonnál jóval nagyobb mértékü természetvédelmi károkat is okozhat. Védett fajok esetében és/vagy védett területeken hatósági engedély nélkül ez a tevékenység (gyüjtés, telepítés) egyébként is illegális.

Igen hasznos lenne, ha az ehhez hasonló, dokumentumokkal is alátámasztható információk a Kárpát-medence más részein is felszínre kerülnének (vö. HANGAY 1889, JUHÁsz 1967, 1968, NAGY 2017). Ilyen adatokból feltehetőleg kevés áll rendelkezésre hazánkban, ennek ellenére közlésüket a hazai flóra jobb megismerése céljából ugyanolyan fontosnak tartjuk, mint a valódi hiányok pótlását. Megjegyzésre érdemes, hogy az „őshonos” fajok jól dokumentált, betelepített vagy termesztett állományait már a korai munkákban (pl. Salvia aethiopis, MoESZ 1911) sem vették figyelembe az areahatárok megrajzolásánál.

\section{Köszönetnyilvánítás}

Ezúton szeretnénk megköszönni Balogh Lajosnak és Takács Attilának az irodalmazásban nyújtott gyors és önzetlen segítségét.

\section{Irodalom}

Bartha D., Király G., Schmidt D., Tiborcz V., Barina Z., CSIKY J., JAKAB G., LeSKu B., SchmotZer A., VidÉKi R., Vojткó A. \& ZóLYomi Sz. (szerk.) (2015): Magyarország edényes növényfajainak elterjedési atlasza. Nyugat-magyarországi Egyetem Kiadó, Sopron, 329 pp.

BARTHA D. \& TiBORCZ V. (2017): Analysis of the Transdanubian region of Hungary according to plant species diversity and floristic geoelement categories. - Folia Oecologica 41: 1-10.

Boros Á. (1952): A Duna-Tisza köze növényföldrajza. - Földrajzi Értesítő 1: 39-54.

ČeřovskÝ J., FerÁková V., Holub J., MaglockÝ Š. \& ProcházKa F. (1999): Červená kniha ohrozených a vzácnych druhov rastlín a živočíchov SR a ČR Vol. 5. Vyššie rastliny. - Príroda a.s., Bratislava

CsıKY J. (2004): A Karancs, a Medves-vidék és a Cerová vrchovina (Nógrád-Gömöri-bazaltvidék) flóra- és vegetációtérképezése. - Magánkiadás, Pécs.

FARKAS S. (szerk.) (1999): Magyarország védett növényei. - Mezőgazda Kiadó, Budapest. 
FElHőSnÉ VÁCZi E., FACSAR G., BÉNYeiné Himmer M. \& RemÉnYiné M. L. (1996): A Medves fennsík körüli bazaltkúpok növényzetének vizsgálata. - A "Lippay János" tudományos ülésszak előadásai és posztereinek összefoglalói. Budapest, 1996. október 17-18., Bp.: KÉE, 1996. pp. 44-45.

HANGAY O. (1889): Erőszakolt flóravidék. - Orvos-természettudományi értesítő II. Természettudományi szak 14: 153-162.

HARASZTHY L. (szerk.) (1998): Magyarország madarai. - Mezőgazda Kiadó, Budapest.

JÁVORKA S. (1925): Magyar Flóra. - Studium, Budapest.

JuHÁSz L. (1967): Kísérletek magashegyi növények meghonosítására a Bükk-fennsíkon. - Az Egri Tanárképző Főiskola Tudományos Közleményei 5: 423-425.

JuHÁSz L. (1968): Kísérletek magashegyi növények meghonosítására a Bükk-fennsíkon II. - Az Egri tanárképző Főiskola Tudományos Közleményei 6: 327-328.

KIRÁLY G. (szerk.) (2004): A Soproni-hegység edényes flórája. - Flora Pannonica 2: 5-507.

KIRÁLY G. (szerk.) (2009): Új magyar füvészkönyv. Magyarország hajtásos növényei. Határozókulcsok. Aggteleki Nemzeti Park Igazgatóság, Jósvafő.

MoEsz G. (1911): Adatok Bars vármegye flórájához. - Botanikai Közlemények 10 (5-6): 171-185.

MolnÁr V. A. (1998): Jövevények a hazai flórában: Betelepítés, kivadulás, flórahamisítás. - Élet és Tudomány 53 (39): 1231-1233.

MoLNÁR V. A. \& LöKI V. (2018): Végveszélyben: a fejfás temetők botanikai és kultúrtörténeti értékei Magyarországon és Erdélyben. - Kitaibelia 23 (1): 51-64.

NAGY B. (2017): Passzív növényvédelem. Növény-áttelepítési kísérleteim eredményei Budapest körzetében. - Növényvédelem 53 (3): 110-119.

Simon T. (2000): A magyarországi edényes flóra határozója. - Nemzeti Tankönykiadó, Budapest

Simon T., Matus G., Pelles G., Tóth Z. \& VojTKó A. (2007): Növényvilág, növénytani értékek. - In: BARÁz Cs. \& Kiss G. (szerk.), A Zempléni Tájvédelmi Körzet. Abaúj és Zemplén határán. Bükki Nemzeti Park Igazgatóság, Eger, pp. 111-140.

SOMLYAY L. (2007): A Ferula sadleriana Ledeb. „újabb” hazai lelőhelye. - Kitaibelia 12 (1): 106-107.

SRAMKó G. (2004): „Dunántúli” közép-dunai flóraválasztós fajok a Matricum flórájában. - Kitaibelia 9: $31-56$.

SRAmKó G., Magos G., MolnÁR Cs. \& URBÁN L. (2008): Adatok a Mátra és környéke edényes flórájának ismeretéhez. - Kitaibelia 13: 74-93.

Soó R. (1964): A magyar flóra és vegetáció rendszertani-növényföldrajzi kézikönyve I. - Akadémiai Kiadó, Budapest.

Soó R. (1970): A magyar flóra és vegetáció rendszertani-növényföldrajzi kézikönyve IV. - Akadémiai Kiadó, Budapest.

Soó R. (1980): A magyar flóra és vegetáció rendszertani-növényföldrajzi kézikönyve VI. - Akadémiai Kiadó, Budapest.

Szmorad F. (2011): The riparian elder forests of the Sopron Hills. - Acta Silv. Lign. Hung. 7: 109-124.

VARGA F. (1994): Cuckoo obseravtions around the source of river Zagyva. - Magánkiadás, Salgótarján.

Beérkezett / received: 2018. 09. 21. • Elfogadva / accepted: 2018.11. 15. 